Carboniferous times, and with which the Shap granite is itself connected.

The metamorphic effects of the granite upon the surrounding rocks are then described. A remarkable set of changes produced in a series of andesites and another of rhyolites, with their respective pyroclastic rocks, is considered in detail, and the results of the netamorphism of the Coniston Limestone series and the Coniston Flags and Grits are given and compared with those obtained by other workers in Norway, the Harz Mountains, and elsewbere.

\title{
CORERSPOINDENTOE.
}

MR. OLDHAM ON THE HIMALAYAS.

Sir,-It is needless to say how much it has pleased me that $\mathrm{Mr}$. Oldham's knowledge of the structure of the Himalayas confirms in his opinion my theory, published in the "Physies of the Earth's Crust," concerning the formation of a mountain range, and of the effects of its subsequent denudation. I wish, however, to point out that the latter are in my work discussed on the hypothesis that the chief streams are formed, and deposit their sediment, on the less steep side of the range. I had rather the instance of the Andes in my mind as a typical range of mountains. With the Himalayas the case is different. The great rivers, Indus and Ganges, after collecting their burden of detritus during long courses between the parallel ridges, finally break through the steep face of the range, and form their deposits on that side. Hence arises the modification of my theory, which Mr. Oldham has found it necessary to make in applying it to the denudation of the Himalayas.

Hartton, Cambridge, $5 F_{t} b .1891$.

MR. MELLARD READE AND THE HERSCHEL-BABBAGE THEORY OF MOUNTAIN BUILDING.

Sir,-The theory of the formation of mountains set forth by me in "The Origin of Mountain Ranges" has been so frequently of late alluded to as a modification of the "Herschel-Babbage" theory, that I shall feel much obliged if one of those who think it so will kindly set forth what the "Herschel-Babbage" theory is. I fear that my friend Mr. O. Fisher is largely responsible for this description of my theory. ${ }^{1}$ I have examined his references to the works of Herschel and Babbage, and must certainly repudiate the labelling as a misdescription. There is no analogy between Herschel's view of the elevation of mountains and mine, and indeed by a sort of dramatic justice I find that Mr. R. D. Oldham ${ }^{2}$ commends Mr. Fisher's work as containing the "most recent and complete adaptation of this (the Herschel-Babbage) doctrine to the theory of mountain formation."

As a matter of fact, the only element in my theory taken from either of these distinguished men is the law discovered by them that the lines of equal internal temperature in the Earth's crust (isogeo-

1 Physies of the Earth's Crust, second edition, p. 132.

2 Geol. Mag. Feb. 1891, p. 73. 
therms) must move upwards into new deposits as they are laid down. This is duly acknowledged in cbap. vii. and credited to Babbage, who, I believe, has priority; but should the use of a natural law in building up a theory disentitle the theoriser to the full right of property in his own theory?

It is said, "What's in a name?" To which I answer, A great deal that is bad when it is vague and misleading and perpetuates errors and misconceptions.

T. Mellard Reade.

Park Corner, Blundellsands, Feb. 9th, 1891.

\section{CRINOIDAL STEMS IN ORDOVICIAN OF SWEDEN.}

SIR,-I am glad to have elicited from Dr. Holm such interesting information about the crinoid stems that be has found in the Leptrnakalk of the Lissberg. But I am sorry that my remark has given rise, perhaps not unnaturally, to some misunderstanding. Dr. Holm in his original notice says two things:-First, that the rock is "chiefly composed of corals, cystids, and crinoid stems ;" secondly, that he himself has found there "erinoid stems belonging to at least two species." Now I never doubted that so experienced a palæontologist as Dr. Holm bad very good reasons for this latter statement; his letter shows how sufficient those reasons were. Nor did I " without having seen a single one of them," venture to assert that all the stem-fragments belonged to Cystidea. I was indeed well aware of the sessile nature of the majority of the Cystidea from this locality. But, remembering as I did how often stems undoubtedly cystidean had been referred to Crinoids, and knowing that not a single Crinoid had been recorded from the Ordovician of Sweden, though 23 species of Cystidea showed the possibility of their preservation, I merely wished, as indeed I still wish, to suggest that some of these ossicles might have pertained to the long and exceedingly crinoid-like stem of Caryocrinus. So inevitable did this seem that, though I did not so far forget either myself or Dr. Holm's very valuable works as to call him a mere collector, still I did express myself in a manner which now seems to me to need an apology, and this I trust, Sir, you will here permit me to offer.

F. A. Bather.

$5 \mathrm{Feb} .1891$.

MOTION OF LAND-ICE.

Sir,-As I have paid some attention to Glaciers, ${ }^{1}$ I shonld like to make a few remarks on the paper by Mr. Goodchild on "The Motion of Land-ice" in the GeoL. MAG. for January last, pp. 19-22.

1. The expansion and contraction of ice for changes of temperature below $0^{\circ} \mathrm{C}$. and under a pressure of one atmospbere is but an example of the general law for solids, which has been recognized for many years in physical science; and the power of ice to resist tensile strain is (as Helmholtz has pointed out) so small as to furnish an explanation of the formation of crevasses, though these are not by any means always produced by contraction due to lowering of temperature. But this very property of ice shows that contraction

1 Q.J.G.S. vol. xxxix. pp. 62-71, "On the Mechanics of Glaciers"; also 'Nature,' vol. xxvii. pp. 553, 554, "On Solar Radiation and Glacier-motion." 